\title{
Debt Financing Option and Financial Performance of Micro and Small Enterprises: A Critical Literature Review
}

\author{
David O. Obuya ${ }^{1}$ \\ ${ }^{1}$ School of Business, University of Nairobi, Nairobi, Kenya \\ Correspondence: David O. Obuya, School of Business, University of Nairobi, Nairobi, Kenya. E-mail: \\ davidobuya65@gmail.com
}

Received: December 14, 2016

Accepted: January 17, 2017 Online Published: February 22, 2017

doi:10.5539/ijbm.v12n3p221

URL: https://doi.org/10.5539/ijbm.v12n3p221

\begin{abstract}
This is a critical literature review on debt financing option and financial performance of Micro and small enterprises. Debt financing option for this review is evaluated in terms of trade credit, short-term loan and long-term loan. Whereas financial performance is evaluated using return on assets, current ratio and gross profit margin. The literatures reviewed include theoretical and empirical. The method used is the review of different articles, papers, and relevant previous studies where quantitative, descriptive, associative and predictive analyses were applied. As per the various literatures reviewed, conflicting findings were realized. A further study on whether effects of debt financing option on financial performance of Micro and Small Enterprises, depend on the power balance between business proprietors and financiers of enterprises, is recommended.
\end{abstract}

Keywords: debt financing option, financial performance, micro and small enterprises, MSEs (Micro and Small Enterprises), KES (Kenya Shillings)

\section{Introduction}

The definition of Micro and Small Enterprises differs from one country to another depending on their staff establishment, value of noncurrent assets (land and buildings exclusive) and rate of turnover (Mensah, 2004). The essence of Micro and Small Enterprises is to create employment opportunities to minimize poverty (Onoja \& Ovayioza, 2015). Micro and Small Enterprises receive funds from the governments, however those which do not receive funds, opt for trade credit, short-term loans and long-term loans from suppliers, relatives, friends, commercial banks and microfinance institutions (Matarirano, 2007). Whether the government funding and debt financing option improve the financial performance of MSEs and guarantee them survival is a puzzle as many of them struggle to remain in operation for long (Coleman, 2001; Hlupeko Duke, 2013). It is therefore, necessary to review the relationship between MSEs debt financing and their subsequent financial performance.

There are various views on the effect of capital structure on the value of the firm. The income operating approach proposes that capital structure is irrelevant, i.e. has no impact on the value of the firm. This position is supported by Modigliani and Miller (1958) who concluded that there is no optimum capital structure level. The alternative theory labeled as the traditional view, posits that capital structure affects the value of the firm.

\subsection{Debt Financing Option}

Debt financing option is the acquisition of capital from a particular lender to run a business and repay it back within a specified period of time with interest in the event of MSEs' retained earnings are inadequate (Hussain, Millman \& Matlay, 2006). Debt financing option is aimed at improving the business earnings, first to recover its cost, then benefit the proprietors, and retain the surplus (Damodaran, 1999). Debt financing option is utilized by both startups, and existing enterprises to expand and get out of tough economic conditions (Hussain et al., 2006). Debt financing option takes the form of trade credit also known as spontaneous credit from suppliers, bank loans, loans from individuals, financial institutions and the governments.

Trade credit may be necessary when MSEs face cash inflows problem that hampers them from purchasing their merchandises on cash basis and at the same time it serves as a safety net when suppliers offer discounts for earlier settlement, conversely suppliers impose penalties on MSEs for breach of contractual obligation (Miwa \& Ramsey, 2008; Cunat \& Garcia, 2012). Trade credit as a spontaneous source of finance could be relatively cheaper compared to bank loan. 
As commercial banks, financial institutions and suppliers open their doors for more borrowers or customers, MSEs prove to be their target clients and ease catch because MSEs also seek for bank loans, trade credit, and support from families or friends, to raise capital (Mensah 2004; Binks \& Ennew, 1996).

MSEs choose debt financing option because, debt it is relatively cheaper, and MSEs' previous creditworthiness is not a considered factor (Graham, 2000; Berger \& Udell 1998). Interest on debt financing is fixed in advance, thus enabling earlier planning and has tax advantage that improves the firm value (Onoja \& Ovayioza 2015; Matarirano 2007). However, debt has direct and incidental costs, including interest, agency and bankruptcy costs, and by its use MSEs suffer from loss of flexibility (Damodaran, 1999).

\subsection{Financial Performance}

Financial performance is the ability of the MSEs to operate efficiently, generate effective income, survive, and expand by observing environmental opportunities and threats (Turyahebya, 2013). Financial performance gauges the proper use of enterprises' resources to maximize profit and wealth (Sollenberg\& Anderson 1995). The monetary financial tasks are performed periodically from the accounts, profit and loss statements or the balance sheets of the Enterprises to measure the extent of their business success (Srinivas2013; Harashet al., 2014).

The Financial reports are used to analyze the performance of the MSEs against the internal and external finances to ensure their proper utilization and prediction of the enterprises' capacity for future eventualities (Levasseur, 2002). It is interesting to note that other than the characteristics of debt that affect the financial performance of MSEs, the power sharing between debt holders and business proprietors may also have an impact on how debt financing option affects financial performance (Berkevitch \& Isral, 1996).

\subsection{Micro and Small Enterprises}

The Micro and Small Enterprises' definitions vary across different countries or regions depending on local operations and conditions such as staff establishment, noncurrent assets and rate of turnover (Mensah 2004). Mensah (2004) therefore, defines Micro enterprises as the enterprises with one to five employees and noncurrent assets worth $\$ 10,000$, and small enterprises as enterprises with six to twenty nine employees or having non-current assets amounting to or less than $\$ 100,000$.

In Kenya micro enterprises are those enterprises with 10 or less workers, small enterprises have between 11 and 50 workers and annual turnover of less than or equal to KES 500,000 as well as capital formation not exceeding KES 5 million according to the Kenya Micro and Small Enterprises Act (2012).

Unlike large enterprises, MSEs survive by resisting harsh economic conditions because of their sizes and flexibility (Rosemond, Daniel, \& Rudolf, 2012). The significance of MSEs of providing employment opportunities that ultimately minimizes poverty has motivated various governments to offer them funds at subsidized interest rates (Onoja \& Ovayioza 2015). Those Micro and Small Enterprises which do not receive funds from the governments resort for trade credit, short-term loans and long-term loans from suppliers, relatives, friends, commercial banks and Microfinance institutions (Matarirano, 2007).

\subsection{Research Problem}

Kenya Economic Survey (2003) shows that micro and small enterprises (MSEs) play a significant role in the socio-economic development process by contributing significantly to overall performance in terms of Gross Domestic Product, creating employment opportunities and exports. They are the pillars of the economy. The level of success of MSEs is depicted in their financial performance, that is the monetary results of enterprises' operations, measured periodically from the accounts, profit and loss statements or the balance sheet to indicate whether firms achieve their purposes, and objectives as laid down in their respective strategic plans (Islam, Khan, Obaidullah, \&Alam 2011; Harashet al.,2014; Harashet al., 2013; Srinivas, 2013).

Micro and Small Enterprises acquire their finances from the governments, commercial banks, microfinance institutions, friends, relatives and trade credit from suppliers for investing in capital and working capital management (Hlupeko Duke, 2013). Debt is anticipated to facilitate MSEs' growth and expansion in order to generate more revenues to cover operational cost, interest on debt itself and return to the proprietors' investment (Onoja \& Ovayioza 2015).

However, whether the use of such debt improves the enterprises' financial performance or not leading to the enterprises' profitability and sustainability is a puzzle (Mensah, 2004; Abor, 2005; Onoja \& Ovayioza, 2015). Despite unlimited access to finances, some MSEs struggle to survive while others are shutting down their operations because of poor financial performance (Hlupeko Duke, 2013; Odhiambo, 2015). Hence this review aims at establishing effects of debt financing on financial performance of micro and small enterprises. 


\subsection{Research Objectives}

The general objective is to establish the documented effects of debt financing option on financial performance of Micro and small enterprises (MSEs) as well as establishing effects of moderating and intervening variables on financial performance of Micro Small Enterprises.

\subsection{Value of the Review}

This review will help to establish some of the factors that are constraining the operations of Micro and small enterprises. The review will also help MSEs to seek for other available cheaper sources of funds that are likely to enhance MSEs financial performance, sustainability, and survival. The non-banking deposit taking institutions in Kenya, will use the review paper to find out reasons why MSEs do not prefer to use their financial services and improve on those areas to increase their customer base and consequently, their profits. The various governments can use this research paper to design policies that are meant to enhance access to credit by MSEs so that they can contribute significantly to their performance that would result in economic development of respective countries.

\subsection{Organization of the Paper}

This literature review consists of four sections organized sequentially as follows:

Section one presents introduction of the review, independent variable, dependent variable, micro and small enterprises, research problem, research objectives, value of the review and organization of the paper.

Section twopresents introduction, review of key theories including optimal capital structure theory, static trade off theory and the pecking order theory, theoretical relationship, measure of variables and section summary.

Section three includes introduction, empirical studies on debt financing and financial performance of MSEs, debt financing, financial performance and risk, debt financing, financial performance and business age, joint effect of debt financing, risk and business age on financial performance, summary of literature review, research gaps and conceptual framework.

Section fouris the summary of the review, conclusion, knowledge gap identified and recommendation for further research. The basic conclusion is that Micro and Small Enterprises should finance their operations with trade credit and long term loan and ensure proper utilization of external finances.

\section{Theoretical Literature Review}

\subsection{Introduction}

A theory is an explanation of observed regularities to explain some empirical observation. A number of theories have been formed to describe the choice of financing, but a generally accepted theory has not been arrived at (Myers 2001). This review focuses only on the capital structure theories which are suitable for the micro and small enterprises.

\subsection{Review of Key Theories}

In section 2.2 is the review of theories, theoretical relationship, measure of variables and section summary.

\subsubsection{Optimal Capital Structure Theory}

Optimal capital structure refers to the best combination of debt and equity that can minimize finance cost, and maximizes a firm value (Roshanak Heshemi, 2013; Bradley, Jarrel, \& Kim, 1984). Optimal capital structure theories therefore, are those theories that suggest how enterprises can maximize their value with a particular percentage of debt.

\subsubsection{The Static Tradeoff Theory}

The static tradeoff theory equates the returns and the cost of debt, whereby the equilibrium point is referred to as the optimal capital structure (Heshemi, 2013). According to the static tradeoff theory, firms select the supreme financial structure by matching the tax benefits of debt, to finance cost including agency and bankruptcy costs (Modigliani \& Miller, 1963). So optimal leverage minimizes cost of capital and maximizes firm value. This infers that profitable enterprises rely on debt financing option because of tax advantage. Remember that interest on debt is deducted from income before tax in the income statement, leading to tremendous tax saving resulting in increased profits (Myers, 2001).

Despite MSEs having advance defined optimal capital structures; there are some constraints that hinder them to get there, such as dearer transaction costs and negligence on the side of the managers to implement the capital structure as advocated by static tradeoff theory (Shyam-Sunder \& Myers, 1999; López-Gracia \& Sogorb-Mira, 2008). 
If the relationship between profitability and leverage is negative, then such a relationship defeats the static tradeoff theory argument of equating cost of debt to benefits of using it, such as tax advantage at the corporate level is cancelled by tax disadvantage at the personal level (Fama \& French, 2002; Heshemi, 2013). The static tradeoff theory is also criticized because the corporate tax gain championed by tradeoff model is insignificant compared with financial distress cost (Miller, 1977).

\subsubsection{The Pecking Order Theory}

Myers and Majluf (1984) developed the pecking order theory which suggests that firms have a particular preference order of raising capital, starting with less risky retained earnings, then safe debt and finally equity. This order is dictated by asymmetric information, released onto the market by each financing category that business managers analyze to make a prudent decision of cost effective source of financing regardless of debt-equity ratio target (Myers \& Majluf, 1984). This suggests that, for firms to improve on their cash flows and increase profits, they need to follow a certain hierarchical fashion of financing their operations starting with least cost source of retained earnings, safe debt and lastly equity.

\subsection{Theoretical Relationship}

\subsubsection{Debt financing Option and Financial Performance}

The major emphasis on theoretical relationship between debt financing option and financial performance is the cost of debt implication and the benefit derived thereafter from its use (Heshemi, 2013). The static tradeoff theory emphasizes on the cost/benefit of debt, where the benefits should overweigh its cost so that the revenue generated must be adequate to cover the operational cost, pay interest on debt itself and meet the business owners' investment returns (Heshemi, 2013). Interest on debt is tax deductable resulting in tax savings that contribute to higher profitability, indicating a clear theoretical relationship between debt financing option and financial performance (Modigliani \& Miller 1963). Therefore, accordingly, debt usage is advantageous because of tax deductibility of its interest on income to arrive at net taxable income, its low-cost nature and facilitation of planning because its interest cost is fixed and known in advance, resulting in better returns to the business owners (Damodran, 1999; Bernstein, 1999).

\subsubsection{Debt financing option, Financial Performance and Risk}

Whereas theoretical emphasis on debt financing and financial performance concentrates on the cost /benefit of debt, systematic and non systematic risks on the other hand, influence this relationship negatively by sweeping out the benefits of debt forcing Saunders and Cornett (2006) to advise enterprise managers to come up with strategies of mitigating these risks. Financial distress cost as well as agency cost and other intervening variables may distort both theoretical and practical relationship between debt financing option and financial performance of MSEs that results in poor financial performance (Heshemi, 2013; Jensen \& Meckling, 1976; Myers, 1977).

\subsubsection{Debt financing, Financial Performance and Age of Business}

As much as theoretical relationship between debt financing option and financial performance seeks to equate costs of debt and benefits derived from its use, age of the business on the other hand modifies their original relationship either positively or negatively. Negatively, financial performance may decline if knowledge, abilities, and skills become outdated with age forcing some MSEs to shut down their businesses while others are merged or acquired whereas positively, older MSEs get highly skilled personnel, customer royalty among other competitive advantages that encourage superior performance and highly promising relationship between the age of a business and its financial performance (Loderer et al., 2009; Agarwal \& Gort, 2002; Sorensen \& Stuart, 2000; Liargovas\& Skandalis, 2008).

\subsubsection{Joint Effects of Debt Financing Option, Risk and Age of Business on Financial Performance}

The impact of debt financing option on financial performance is conflicting in a way that positive, negative, and non-relationships are depicted in literatures reviewed (Amirkhani \& Fard, 2009; Myers \& Majluf, 1984; Ebaid, 2013). Risk has a negative impact on financial performance, and its management is essential to allow financial performance to prosper well without interference as agitated by Saunders \& Cornett (2006) in his study. Age has either negative or positive effects on financial performance of MSEs, because the argument is that financial performance may decline or prosper with age (Lodereret al., 2009; Agarwal \& Gort, 2002; Sorensen \& Stuart, 2000; Liargovas \& Skandalis, 2008).

\subsection{Measure of Variables}

The most important objective for the business is to earn adequate returns necessary to cover the costs of sales, repay outstanding loans and other overheads, pay business owners returns, and ultimately retain the surplus for 
re-investment and provision of additional working capital (Hashemi, 2013). Financial performance is measured using the approach by Trochim (2004). The approach falls under the class of statistical estimation. Approaches to financial performance measures include; current ratio computed as current assets divided by current liabilities, gross profit margin calculated as gross income divided by sales, and return on assets calculated as earnings before interest and tax divided by total assets. Debt financing is measured in terms of trade credit, long-term and short-term loans whose ratios of usage are established by dividing each portion of debt by the total debt (Ebaid, 2013; Emad \& Alsaadi, 2014, Harash et al., 2014).

Return on assets (ROA) is a measure of how efficient an enterprise uses its assets to generate adequate profits indicating profitability of MSEs before leverage (Harash\&Essia, 2013).

Debt financing is measured in terms of trade credit, long-term loans and short-term loans. The debt ratio is measured as a ratio of total debt to total assets (dividing total debts with total assets). The ratio shows how assets cover liabilities (Manas'seh, 1990).

\subsection{Section Summary}

Myers (2001) argues that capital structure theory choice is not standardized. However the best combination of equity and debt known as optimal capital structure is the one that minimizes the financing cost, and maximizes the value to the firms by giving the best balance between tax benefits and distress cost (Roshanak Heshemi, 2013; Bradley, Jarrel, \& Kim, 1984). The static Tradeoff Theory equates the benefits and the cost of using debt where the optimal capital structure occurs when the benefit and cost are optimal (Heshemi, 2013). Myers and Majluf (1984) developed the pecking order theory which suggests that firms have a particular preference order for raising capital.

\section{Empirical Literatures}

\subsection{Introduction}

This section focuses on the review of empirical literature on effects of debt financing option on financial performance of MSE's.

\subsection{Empirical Study}

Empirical research is a way of gaining knowledge by means of direct and indirect observation or experience.

\subsubsection{Debt financing option and MSEs Financial Performance}

The relationship between debt financing option and financial performance of MSEs is discussed singularly and severally as hereunder. Trade credit is a short-term loan suppliers provide to their customers upon purchase of merchandise for sale. It is one of the key debt financing options for micro and small enterprises, which does not need to be secured and customers' previous credit worthiness is not required (Vicente \& Emilia, 2012; Shinichi, Kasuya,\&Akash, 2006). It is used as an alternative credit facility to bank loans and when MSEs face unforeseeable cash flow constraints (Miwa \& Ramsey, 2008; Dermirguc-Kunt \& Maksimovic, 2001).

Trade credit is advantageous to MSEs because of transaction cost reduction that could have been incurred if payment was to be made instantly on delivery of goods (Nadiri (1969). However trade credit is associated with MSEs' liquidation that forces them to look for alternative financing options (Wilner, 2000; Cuñat, 2003). As conditional terms, the supplier may require payment for the goods to be made within a certain specific period of time after delivery, and offer a discount or charge penalties when the buyer breaches the contractual obligation, raising the cost of trade credit (Denisova, 2000; Vicente \& Emilia, 2012).

Long-term debt is raised by financially stable enterprises, for a period of seven years and above, secured by collaterals (Manas'seh, 1990). The MSEs use more of long-term debt expecting that financial performance shall improve (Amirkhani \& Fard, 2009). In practice, long-term investments are supported by proper utilization of long-term loan to generating sufficient profits to repay loans, cover all costs, and distribute the surplus accordingly (Amirkhani\&Fard, 2009; Pelham, 2000; Pelham \& Wilson, 1996).

MSEs' over dependence on long-term loan hampers business owners from recouping the Capital invested, increase finance cost and the chance of bankruptcy is imminent (Myers, 1997; Rajan, 1992; Roshanak, 2013). However, long-term loan depicts no significant relationship with financial performance as measured by return on assets and gross profit margin (Ebaid, 2013).

Short-term loan is given to the enterprises known to the bank, for a period of four years and below (Manas'seh, 1990). MSEs borrow short-term loan because it is cheaper and does not require security but rather the firm's reputation (Weinraub \& Visscher, 1998). Short-term loan depicts conflicting effects on MSEs financial 
performance that is positive, negative and no relationship at all as measured by gross profit margin and return on assets (Ebaid, 2013).

\subsubsection{Debt Financing Option, Financial Performance and Risk}

Risk influences the relationship between debt financing option and financial performance of MSEs negatively, calling for remedial actions to be taken to mitigate risks (Saunders \& Cornett, 2006). The effect of debt financing on financial performance has mixed results, Matarirano (2007) but when an intervening risk variable occurs, the effect is negative. On the contrary, increase in debt put the MSEs at high risk of bankruptcy. Moreover, debt financing may exert pressure on MSE management to guarantee improved financial performance to cover debt obligations.

\subsubsection{Debt Financing Option, Financial Performance and Business Age}

Business age as a moderating factor modifies the relationship between debt financing and financial performance, because MSEs' financial performance may either improve or decline as they grow older (Loderer et al., 2009; Agarwal \& Gort, 2002; Sorensen \& Stuart, 2000; Liargovas \& Skandalis, 2008). This is supported by learning curve approach, which is based on the principle that firms become better or worse at their tasks which are executed repeatedly.

\subsubsection{Joint Effect of Debt Financing Option, Risk and Age of Business on Financial Performance}

Unlike risk which has a definite negative relationship with financial performance, debt financing option and business age have mixed effects on financial performance (Saunders \& Cornett, 2006; Matarirano, 2007; Agarwal \& Gort, 2002; Sorensen \& Stuart, 2000; Liargovas \& Skandalis, 2008). Financial performance when measured by gross profit margin, return on assets and current ratio depicts positive relationship with moderate debt financing usage (Abor, 2005; Modigliani \& Miller, 1963; Cecchetti, Mohanty, \&Zampolly, 2011; Rainhart\&Rogoff, 2009).

However, in certain cases, when excess debt financing is used, ceteris paribus,financial performance indicates negative relationship with debt financing option that may, to a certain extent induce bankruptcy cost (Al-Timimi\&Alsaadi,2014; Cecchetti, Mohanty, \& Zampolly, 2011). As mentioned earlier, financial performance measured by gross profit margin has insignificant relationship with debt financing (Ebaid, 2013).

\subsection{Summary of Empirical Literature Review and Research Gaps}

The reviews manifested conflicting effects of debt financing option on financial performance of MSEs (Myers \& Majluf 1984; Daskalakis \& Psillaki 2008; \&Vasiliou et al., 2009; Rajan 1992). Because of the high cost of long term debt as portrayed by the literature reviews, the chance of MSEs being put under receivership is real and eminent (Roshanak Heshemi, 2013). Further revelation that may draw the researcher off balance from the reviews indicates that, there is no significant relationship between debt financing and financial performance as measured by long-term loan and return on assets (Ebaid, 2013). Trade credit generally perceived to solve the short term cash flows problem of MSEs, proved to work against them as it is associated with higher cost caused by penalties charged on delayed payment and high levels of default opening the wide gate to liquidation of the enterprises (Wilner, 2000;Cuñat, 2003; Cuñat \& Garcia, 2012).The mixed results of effects of debt financing on financial performance are further manifested in the work of Amirkhani and Fard (2009) and Pelham (2000) where, after thorough review a positive relationship was established between debt financing and financial performance.

Trade credit may motivate business owners to go for more of it because it reduces transaction costs and payment for the machandise are made later on rather than cash on delivery (Nadiri, 1969; Nielsen, 2000; Smith, 1987; Lee \& Stowe, 1993; Long, Maliz, \& Ravid, 1994;Ferris, 1981).

The research gap identified is effects of debt financing option on financial performance of Micro and Small Enterprises. MSEs go for debt financing option, mainly because debt is relatively cheaper and no requirement for previous firms' creditworthiness (Graham, 2000; Berger \& Udell, 1998). Interest on debt is fixed in advance, thus enabling advance planning. In addition, debt capital has tax advantages that improve the firm value (Onoja \& Ovayioza, 2015; Matarirano, 2007). However, debt has direct and incidental costs, such as interest, agency and bankruptcy costs, and as if that is not enough MSEs also suffer from loss of flexibility (Damodaran, 1999).

\subsection{Conceptual Framework}

Conceptual Framework Linking Debt Financing option to Financial Performance 


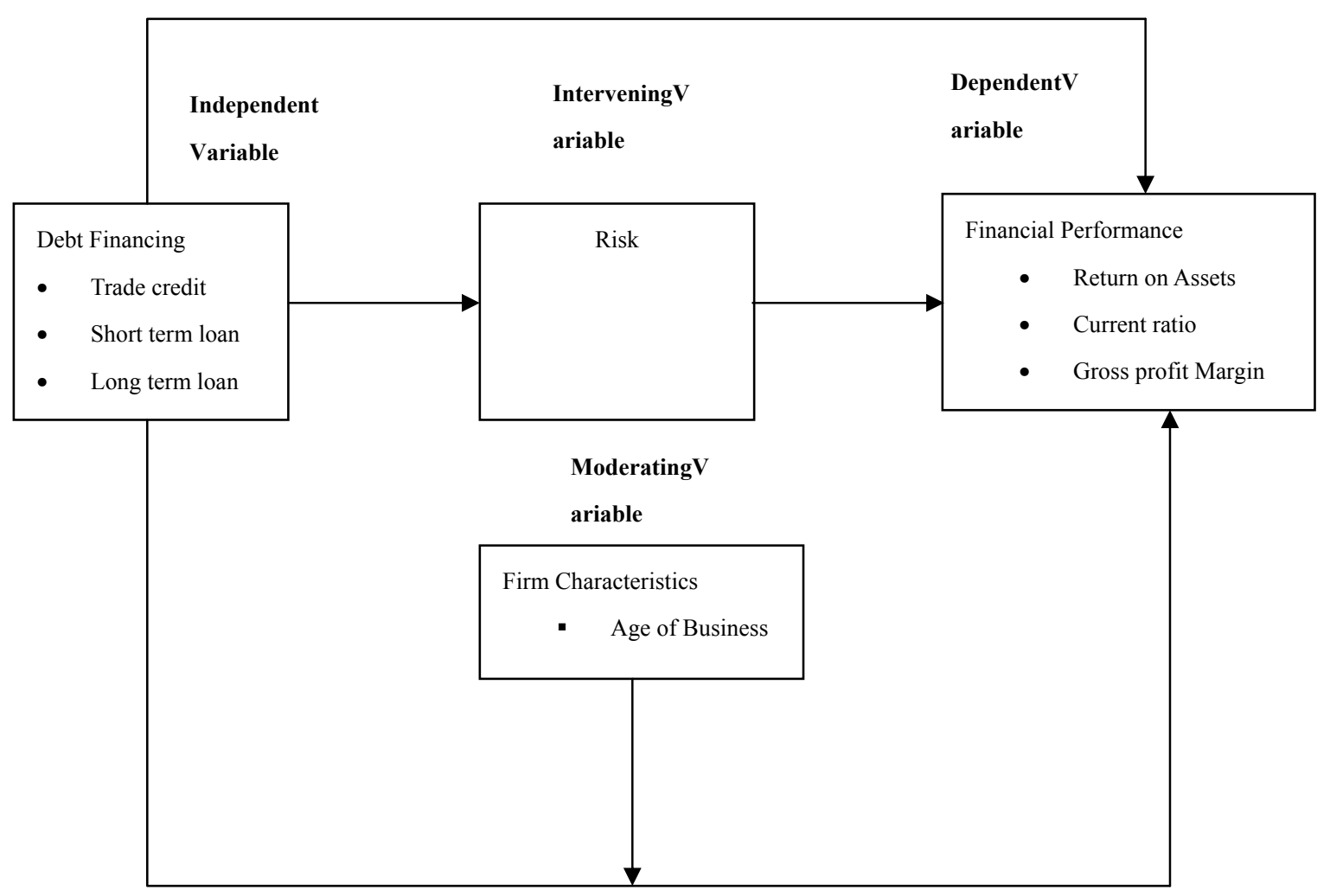

Figure 1. Conceptual model

The relationship of the independent variable is reviewed to establish if there is any relationship between its identified constructs and financial performance. Debt financing option affects financial performance positively as measured by gross profit margin and return on assets (Amirkhani \& Fard, 2009; Pelham, 2000).

However studies by Daskalakis and Psillaki (2008), Vasiliou et al. (2009), Rajan (1992) and Myers amd Majluf (1984) show a negative relationship between debt financing option and financial performance. Ebaid (2013) found no significant relationship between debt financing option as measured by long-term loan and return on assets. Business age has dual relationship with financial performance of MSEs as Loderer et al. (2009) champions the argument that the effect can either be positive or negative as the enterprises grow older. Risks, being intervening variables can bring down the enterprises' operations if they are not identified in advance to be mitigated because their effects on financial performance is obviously negative and disastrous (Saunders \& Cornett 2006).

\section{Summary, Conclusion and Recommendation}

This section comprises of the summary, conclusion and recommendation for further study.

\subsection{Summary}

From the review of various articles, papers and literatures, there are conflicting findings on effects of debt financing option on financial performance of Micro and Small Enterprises. Mixed results of positive, negative and no relationship between debt financing option and financial performance measured in terms of trade credit short-term loan, and long-term loan, on one hand and return on assets, current ratio and gross profit margin on the other hand were generated (Myers \& Majluf, 1984; Daskalakis, \& Psillaki, 2008; Vasiliou, Eriotis, \& Daskalakis, 2009; Myers, 1997;Amirkhani\&Fard, 2009).

\subsection{Conclusion}

From the findings of the review of previous studies, articles and papers on effects of debt financing option on financial performance of Micro and Small Enterprises, a number of conflicting conclusions were made. Trade credit is linked with firms' liquidation and default payment hence has a negative effect on financial performance. There is a negative relationship between short term loans on enterprise financial performance measured by return on assets. If enterprises depend more on long-term debt, they are likely to increase their cost of capital and 
finally collapse. Total debt is a predictor of non-performance on MSEs because it impacts negatively both on return on assets and gross profit margin.

On the other hand, Trade credit decreases costs of transactions. Enterprises that increase short-term loan hold more cash that improves their cash flows. Long-term loan has a positive effect on financial performance, measured by return on asset. Total debt has a positive effect on financial performance measured by gross profit margin.

Financial performance measured by gross profit margin depicts insignificant relationship with debt financing option. There is no significant relationship between long-term debt and return on assets. There is insignificant relationship between total debt and financial performance measured by gross profit margin. In conclusion, Micro and Small Enterprises should finance their operations with trade credit and long-term loan and ensure proper utilization of external finances.

\subsection{Knowledge Gap Identified}

The knowledge gap identified is effects of debt financing option on financial performance of Micro and Small Enterprises.

\subsection{Recommendation for Further Study}

A further study on whether effects of debt financing options on financial performance of Micro and Small Enterprises depend on the power balance between owners of the business and debt holders is recommended. This has been prompted by the mixed results from the review of previous literatures, articles and papers on the effect of debt financing on financial performance of Micro and Small Enterprises. The curiosity of one tail test of either negative or positive result of effect of debt financing on financial performance of MSEs has driven the researcher to recommend for this further study.

\section{Acknowledgement}

I acknowledge my mentors Dr. Otieno and Dr. Iraya. I am most grateful and deeply indebted for the tangible help and guidance they fundamentally imparted in my work and for giving me their time to guide me throughout. I am deeply indebted to their mentoring, encouragement, support and discipline.

I acknowledge my family at large. It is a great measure of humility to thank you for your love, support and serenity. I am truly blessed and honored to have you as my family.

\section{References}

Abor, J. (2005). The effect of capital structure on profitability: An empirical analysis of listed firms in Ghana. The Journal of Risk Finance, 6(5), 438-445.

Agarwal, R., \& Gort, M. (2002).Firm and Product Life Cycles and Firm Survival. American Economic Review, 92(2), 184-190.

Almajali, A. Y., Alamro, S. A., \& Al-Soub, Y. Z. (2012). Factors Affecting the Financial Performance of Jordanian Insurance Companies Listed at Amman Stock Exchange. JmrJournal of Management Research, $4(2)$.

Almeida, H., Campello, M., \& Weisbach, M. S. (2004). The Cash Flow Sensitivity of Cash. SSRN Electronic Journal SSRN Journal.

Amirkhani, A., \& Far, R. S. (2009). The Effect of Market Orientation on Business Performance of the Companies Designing and Manufacturing Clean Rooms. American Journal of Applied Sciences American J. of Applied Sciences, 6(8), 1573-1579.

Amjed, S. (2007). Impact of Financial Structure on Firm's Performance: A Study of Pakistan's Chemical Sector. Management of International Business and Economic System, 440-450.

Andree, C., \&Kallberg, C. (2013). The Capital Structure Puzzle of SME's - Evidence from the Swedish security industry. Retrieved from http://ww.student.se/uppsok/search2phpallasmes

Athanasoglou, P. P., Brissimis, S. N., \& Delis, M. D. (2005). Bank-specific, industry-specific and macroeconomic determinants of bank profitability. Journal of International Financial Markets, Institutions and Money, 18(2), 121-136.

Berkovitch, E., \& Israel, R. (1996). The Design of Internal Control and Capital Structure. Review of Financial Studies, 9(1), 209-240.

Bernstein, L., \& Wild, J. (1997). Financial statement analysis: Theory, application, and interpretation. Chicago, 
IL: Irwin.

Binks, M. R., \& Ennew, C. T. (1996). Growing firms and credit constraint. Small Business Economies, 8, 17-25.

Bradley, M., Jarrell G., \& Kim E.H., (1984). On the Existence of an Optimal Capital Structure: Theory and Evidence. Journal of Finance, 39, 857-878.

Capon, N., Farley, J. U., \& Hoenig, S. (1996). Determinants of Financial Performance: A Meta-Analysis. Management Science, 36(10), 1143-1159.

Cecchetti, G. S., Mohanty, M. S., \& Zampolly, F. (2011). The real Effects of Debt.

Coleman, S., \& Cohn, R. (2001). Small Firms' use of Financial Leverage: Evidence from the 1993 National Survey of Small Business Finances. J. Bus. Entrepreneurship, 12(3), 81-98.

Cunat, V. (2003). Trade Credit: Suppliers as debt collectors and insurance providers. Review of Financial Studies, 20, 491-527

Cuñat, V., \& Emilia, G. A. (2012). Trade Credit and its Role in Entrepreneurial Finance. In Cumming, D. (Ed.), Oxford Handbook of Entrepreneurial Finance. Oxford University Press, New York.

Damodaran, A. (1999). Applied Corporate Finance. New York: John Wiley \& Sons, Inc.

Daskalakis, N., \& Psillaki, M. (2008). Do Country of Firm Factors Explain Capital Structure? Evidence from SMEs in France and Greece, Applied Financial Economics, 18, 87-97

Demirguc-Kunt, A., \& Maksimovic, V. (2001). Firms as Financial Intermediaries: Evidence from Trade Credit Data. Unpublished working paper. World Bank and the University of Maryland.

Denisova, I., (2000). Credit Channel of Monetary Transmission. The Role of Industrial Inter-enterprise Arrears. Working Paper, nº.99/12, Economics Education and Research Consortium.

Dube, H. (2013). The impact of debt financing on productivity of small and medium scale enterprises (SMEs): A case study of SMEs in Masvingo urban. International Journal of Economics, Business and Finance, 1(10), 371-381.

Ebaid, I. E. (2013). The Impact of Capital- Structure choice on Firm Performance: Empirical Evidence from Egypt. The Journal of Risk Finance, 10(5), 477-487.

Emad, H., Al-Timimi, S., \& Alsaadi, J. (2014). The Influence of Finance on Performance of Small and Medium Enterprises (SMES). International Journal of Engineering and Innovative Technology (IJEIT), 4(3).

Fama, E. F., \& French, K. R. (2002). Testing Trade-Off and Pecking Order Predictions about Dividends and Debt. The Review of Financial Studies, 15(1), 1-33.

Ferris, J. S. (1981). A Transactions Theory of Trade Credit Use. Quarterly Journal of Economics, 96(2), 243-270

Graham, J. R. (2000). How Big are the Tax Benefits of Debt? Journal of Finance, 55(5), 1901-1941.

Harash, E., Al-Tamimi, K., \& Al-Timimi, S. (2014). The Relationship between Government Policy and Financial Performance: A Study on the SMEs in Iraq. Journal China-USA Business Review, 13(4).

Harash, E., Fatima, J. A., \& Essia, R. A., (2013). Moderating Effect of Market practices on the Government policy -Performance Relationship in Iraq SMEs. 4th Global Conference for Academic Research on.Economics, Business and Management. (GCAR-EBM) 29-30- 2013 Kuala Lumpur, Malaysia.

Hashemi R. (2013). The Impact of Capital Structure Determinants on Small and Medium size Enterprise Leverage An Empirical Study of Iranian SMEs, Södertörn University, Institution for Social Science, (Unpublished Thesis).

Hlupeko, D. (2013). The Impact of Debt Financing on Productivity of Small and Medium Scale Enterprises (SMEs): A Case Study of SMEs in Masvingo Urban. International Journal of Economics, Business and Finance 1(10), 371-381,

Hussain, J., Millman, C., \& Matlay, H. (2006). SME financing in the UK and in China: a comparative perspective. Journal of Small Business and Enterprise Development, 13(4), 584-599.

Hvide, H. K., \& Moen, J. (2007). Liquidity Constraints and Entrepreneurial Performance.

Islam, M. A., Khan, M. A., Obaidullah, A. Z. M., \& Alam, M. S. (2011). Effect of entrepreneur and firm characteristics on the business success of small and medium enterprises (SMEs) in Bangladesh. International Journal of Business and Management, 6(3), 289. 
Juhl, H. J., Kristensen, K., \&Østergaard, P. (2002). Customer Satisfaction in European Food Retailing. Journal of Retailing and Consumer Services, 9(6), 327-334.

Kayo, E. K., \& Limura, H. (2010). Hierarchical Determinants of Capital Structure. Journal of Banking \& Finance, 35, 358-371.

Lee, Y. W., \& Stowe, J. D., (1993). Product Risk, Asymmetric Information, and Trade credit.Journal of Financial and Quantitative analysis, 28, 285-300.

Levasseur, C. (2002). Business Value of IT- Non-performance Measurements. International Edition, Oxford printing press, London.

Liargovas, P., \& Skandalis, K. (2008). Factor affecting firms financial performance: The Case of Greece. Athens: University of Peloponnese Press.

Loderer, C., Neusser, K., \& Waelchli, U. (2009). Firm age and survival. Switzerland: Working paper, University of Bern.

Long, M S., Malitz I. B., \& Ravid, S. A. (1994). Trade credit, quality guarantees, and product marketability. Financial Management, 22(4), 117-127.

Lopéz-Gracia, J., \& Sogorb, M. F. (2008). Testing Trade-Off and Pecking Order theories financing SMEs. Small Business Economics, 38, 117-136. http://dx.doi.org/10.1007/s11187-007-9088-4

Manas'she, P. (1990). A Textbook for Business Finance. Nairobi. Mc More Accounting Books

Matarirano, O. (2007). An investigation into the Impact of Debt Financing on the Profitability of Small Manufacturing Firms in Bulawayo, Zimbabwe. Sub-Saharan Africa: International Business Conference, Pretoria, September 2007.

Mensah, S. (2004). A Review of SME Financing Schemes in Ghana. UNIDO Regional Workshop of Financing, SMEs, 15-16 March, Accra.

Michael L. Roberts, M. R., \&Zender, J. F. (2009). Back to the Beginning: Persistence and the Cross-Section of Corporate Capital Structure. The Journal of Finance, 63, 1575-1608

Miller, M. H. (1977). Debt and Taxes. The Journal of Financing, 32(2), 261-275.

Modigliani, F., \& Miller M. H. (1958). The Cost of Capital, Corporation Finance and the Theory of Investment. The American Economic Review, 68(3), 261-297.

Modigliani, F., \& Miller, M. H. (1963). Corporate Income Taxes and the Cost of Capital: A Correction. The American Economic Review, 53(2), 433-443.

Myers, M. (1997). Interpretive Research in Information Systems. In J. Mingers \& F. Stowell (Eds.), Information systems: An Emerging Discipline. McGraw Hill, London.

Myers, S. (1977). Determinants of Corporate Borrowing. Journal of Financial Economics, 5, 147-175. http://dx.doi.org/10.1016/0304-405X(77)90015-0

Myers, S. C. (2001). Capital structure. Journal of Economic Perspectives, 15, 81-102.

Myers, S. C., \& Majluf, N. (1984). Corporate Financing and Investment Decisions when Firms have Information That Investors do not have. Journal of Financial Economics, 13, 187-221.

Nadiri N. I. (1969). The Determinants of Trade Credit Terms in the U.S. Total Manufacturing Sector. Econometrica, 37, 408-423.

Nilsen, J. H. (2002). Trade Credit and the Bank Lending Channel. Journal of Money, Credit and Banking, 34.

Odhiambo L.O. (2015). The Relationship between Capital Structure, Performance and Replacement of CEO in Firms Listed on the Nairobi Securities Exchange. University of South Africa (unpublished PhD Thesis).

Onoja, E. E., \& Ovayioza, S. P. (2015).Effects of Debt Usage on the Performance of Small Scale Manufacturing Firms in Kogi State of Nigeria. International Journal of Public Administration and Management Research (IJPAMR), 2(5).

Pelham, A. M. (2000). Market Orientation and other Potential Influences on Performance in Small and MediumSized Manufacturing Firms. Journal of Small Business Management, 38, 48-67

Pettit, R., \& Singer, R. (1985). Small Business Finance: A Research Agenda. Financial Management, 14, 97-112. 
Rajan, R., \& Zingales, L. (1992). What Do We Know about Capital Structure? Some Evidence from International Data. Journal of Finance, 50, 1421-1460.

Reinhart, C. M., \& Rogoff, K. S. (2009). This Time Is Different: Eight Centuries of Financial Folly. Princeton: Princeton University Press.

Rosemond, B., Daniel, A., \& Rudolf, A. (2012). A Micro level Analysis of the Market Orientation- Small Business Financial Performance Nexus. American International Journal of Contemporary Research, 2(1).

Sandberg, K., Vinberg, S., \& Pan, Y. (2002). An exploratory study of women in micro enterprise; owner perceptions of economic policy in a rural municipality: Gender-related differences. In CD-proceedings of 12th Nordic Conference on Small Business Research. Creating Welfare and Prosperity through Entrepreneurship.

Saunders A., \& Cornett, M. (2006). Financial Institutions Management: A Risk Management Approach (5th ed.). McGraw-Hill International Edition.

Shinichi, F., Kasuya M., \& Akashi, K. (2006). The role of trade credit for small firms: An implication from Japan's banking crisis. 'CIRJE Discussion Paper Series, The University of Tokyo.

Shyam-Sunder, L., \& Myers, S. C. (1999). Testing Static Tradeoff against Pecking Order Models of Capital Structure. Journal of Financial Economics, 51, 219-244.

Simerly, R., \& Li, M. (2000). Environmental dynamism, financial leverage and performance: A theoretical integration and an empirical test. Strategic Management Journal, 21(1), 31-49.

Smith, J. (1987). Trade Credit and Informational Asymmetry. Journal of Finance, 42, 863-869.

Srinivas, K. T. (2013). An Analysis of Financial Statements of Karnataka State Finance Corporation. International Journal of Engineering and Management Research, 3, 59-63.

Titman, S., \& Wessels R. (1988). The Determinants of Capital Structure Choice. The Journal of Finance, (1), $1-19$.

Turyahebwa, A. (2013). Financial Performance in the Selected Microfinance Institutions. Uganda (unpublished master's thesis) Kampala International University, West campus.

Vasiliou D., Eriotis N., \& Daskalakis, N. (2009). Testing the Pecking Order Theory: the Importance of Methodology. Qualitative Research in Financial, 1(2), 85-96.

Vicente, C., \& Emilia, G. A. (2012). Trade Credit and its role in entrepreneurial finance. Oxford Handbook of Entrepreneurial Finance. New York: Oxford University Press.

Wang, C. K., \& Ang, B. L. (2004). Determinants of venture performance in Singapore,” Journal of Small Business Management, 42(4), 347-363.

Watson, R., \& Wilson, N. (2002). Small and Medium Size Enterprise Financing: A Note on Some of the Empirical Implications of a Pecking Order. Journal of Business Finance \& Accounting, 29(3), 557-578.

Wilner, B. S. (2000). The Exploitation of Relationships in Financial Distress: The Case of Trade Credit. The Journal of Finance, 15(1), 153-178.

Wilson, N., \& Peel, M. J. (1996). Working capital and financial management practices in the small firm sector. International Small Business Journal, 14(2), 52-68.

\section{Copyrights}

Copyright for this article is retained by the author(s), with first publication rights granted to the journal.

This is an open-access article distributed under the terms and conditions of the Creative Commons Attribution license (http://creativecommons.org/licenses/by/4.0/). 